Williams, H. 2015. Hogbacks: the materiality of solid spaces, in H. Williams, J. Kirton and M. Gondek (eds) Early Medieval Stone Monuments: Materiality, Biography, Landscape. Woodbridge: Boydell and Brewer, pp. 241-68.

http://www.boydellandbrewer.com/store/viewltem.asp?idProduct=14947

\title{
Hogbacks: the Materiality of Solid Spaces
}

\author{
Howard Williams
}

\section{Introduction}

The hogbacks of northern England and southern Scotland have long been seen as a distinctive category of tenth- and early eleventh-century early medieval stone monument resulting from Hiberno-Norse influence and settlement. This chapter reviews previous research and suggests a new foundation for their interpretation, arguing that hogbacks were an effective commemorative media because of the mnemonics of their materiality. Specifically, I focus upon the skeuomorphic allusions inherent in the ornamentation and form of hogbacks. Combined with their solidity and lithic weight, hogbacks cited a multi-scalar network of architectural material cultures and buildings already established within Britain and Ireland prior to, as well as during, the Viking Age. Rather than exclusive translations of secular halls into stone as often portrayed in both popular and scholarly research (e.g. Stocker 2000; Eriksen 2013), hogbacks cited a complex network of buildings (including secular halls but potentially also churches) and small-scale architectures (from biers and coffins to caskets and reliquaries) which were distilled into a solid lithic architectural form in various fashions. In this regard, hogbacks operated as elite commemorative monuments because their form connected to this shared elite network of architectural 'things' and implied the presence of the dead as inhabiting, or at least accessible through, the monument. Endbeasts and other themes of conflict were apotropaic in this context. The monstrous, sometimes ursine, beasts threaten to engulf some hogbacks - although sometimes they are demonstrably curtailed by their binding and muzzling. The emphasis upon bound beasts reveals the significance of sealing and fixing the tomb in place through its hogback design.

This approach aims to embrace, rather than obscure, the internal variability of the hogback tombs by focusing on their architectural materiality and lithic solidity as well as the hitherto close attention afforded to hogbacks' form and ornamentation. Hence, hogback tombs were a commemorative strategy that installed and bound the dead in place within the church or churchyard by citing not a single source of influence but a range of other mythical and biblical as well as quotidian architectural spaces in which heroes, saints and other powerful figures were honoured and recalled. Hogbacks created a mnemonic network linking imagined pasts and projected aspired futures for the groups creating, installing and performing around them. Hogbacks can therefore be subtly but significantly resituated in interpretations of tenth- and eleventh-century northern Britain as a specific strategy of linking elite bodies to specific mortuary locations and protecting them from unwanted physical intervention and spiritual harm. This chapter sees no reason why those of Norse and native descent alike might not adopt this commemorative medium within a postcolonial context as well as one of socio-political and religious fluidity. 
The pertinence of this theme to this book lies in the attention to the weight, solidity and skeuomorphic materiality of a category of early medieval carved stone grave-covers. As such, hogbacks created the sense of an absent presence, citing the body (or bodies) of the dead beneath or elsewhere, and affording the sense of an inhabited tomb, akin to the shrines of saints. Moreover, this approach shifts the interpretation of hogbacks from being an index of Norse settlement to a technology of corporeal and architectural commemoration that would have made a powerful statement to Insular audiences as well as those of HibernoNorse origin.

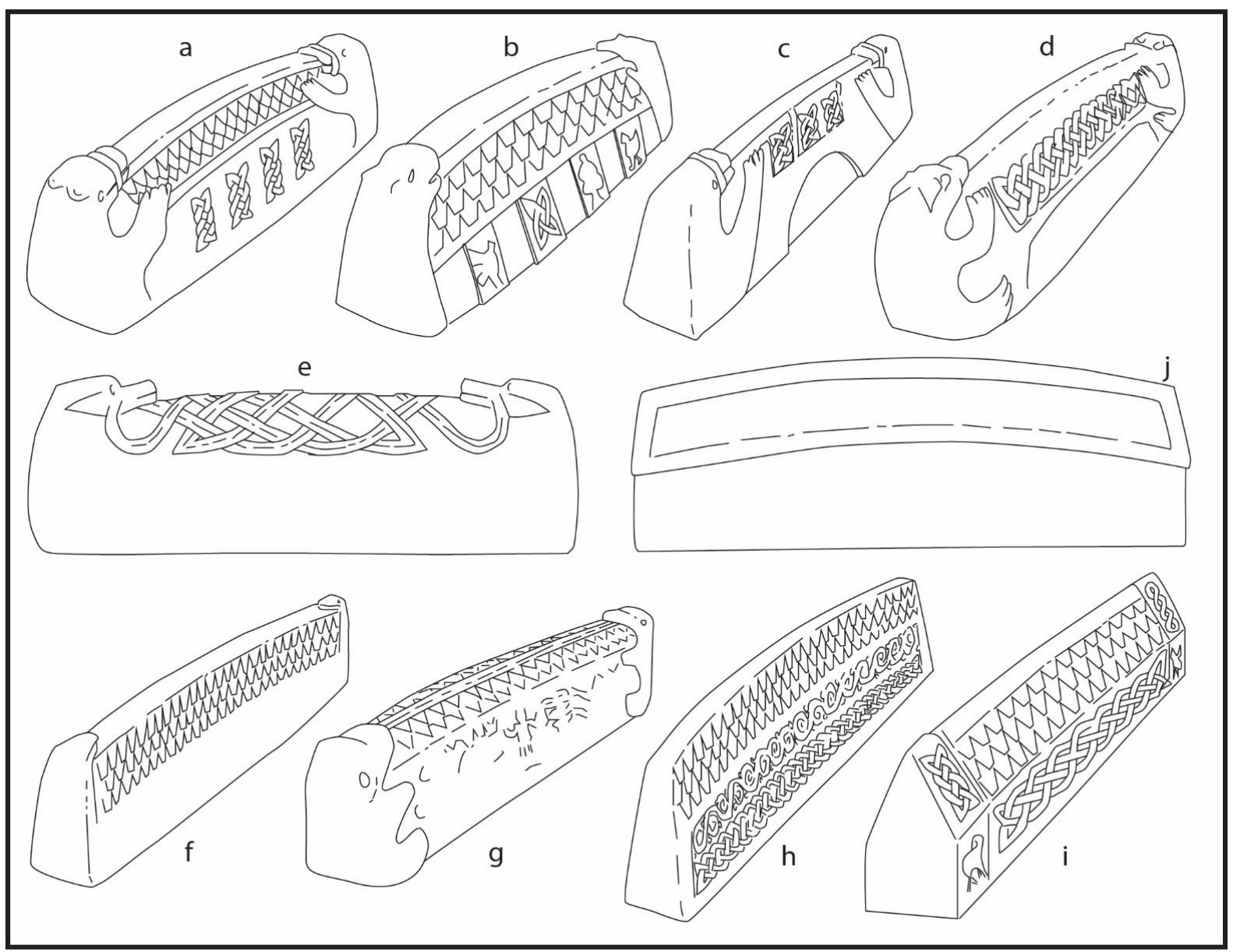

Fig. 9.1 Schematic representations of the ten sub-types of hogback tomb recognized by the Corpus of Anglo-Saxon Stone Sculpture. Lang's rare wheel-rim type and the Scottish End-beast types are not depicted.

\section{Introducing hogbacks}

For over a century the early medieval commemorative monuments known as 'hogbacks' perhaps more neutrally referred to as a specific range of 'coped stones' (Preston-Jones and Okasha 2013, 163) - have intrigued and frustrated early medieval scholarship (see Collingwood 1927, 164-73). As part of the rapid increase in the volume of sculptural production in the tenth century, including the rise of recumbent grave-slabs at this time (see Stocker 2000), hogbacks are distinctive but incredibly varied. The lack of a consistent and pervading form for the hogback monument is exemplified by Lang's research (1972-74i 1984). Lang created a complex classification of the monuments into eleven different sub- 
types (see also Cramp 1984a, xix-xx: ten of these, excluding a distinctive Scottish variety, are reproduced in Fig. 9.1). These types are distinguished by the presence/absence and character of the end-beasts and the character of their ornament. Despite this variety, which might prepare us in accepting that any single interpretation of these monuments might prove challenging (e.g. Hall 2015), many share in having a bow-walled, building-shaped form with a curved ('hogbacked') roof, often (but not always) framed by end-beasts that embrace and often also press their (usually bound) muzzles over the gable-ends. Illustrative scenes appear on a minority and, where present, they focus on mythological conflicts with beasts and monsters, with some scenes interpreted as depicting stories from Norse mythology (Kopár 2012).

While there are local concentrations, perhaps 'workshops', producing these styles (Lang 1984, 88), it is important to emphasize that many of Lang's sub-types have wide and interleaving distributions (e.g. Bailey and Cramp 1988, 29). Therefore, their form is eclectic even from a local perspective. For example, Brompton (North Yorks.) has three sub-types (a, c and d: Lang 2001, 23, 74-9), Lythe (North Yorks.) has four (e, i, j and k: Lang 2001, 159-66) and Sockburn-on-Tees (Durham) has at least four, possibly five (c, d, f, g and possibly j; Cramp 1984b, 140-44; Lang 1984, 162-6).

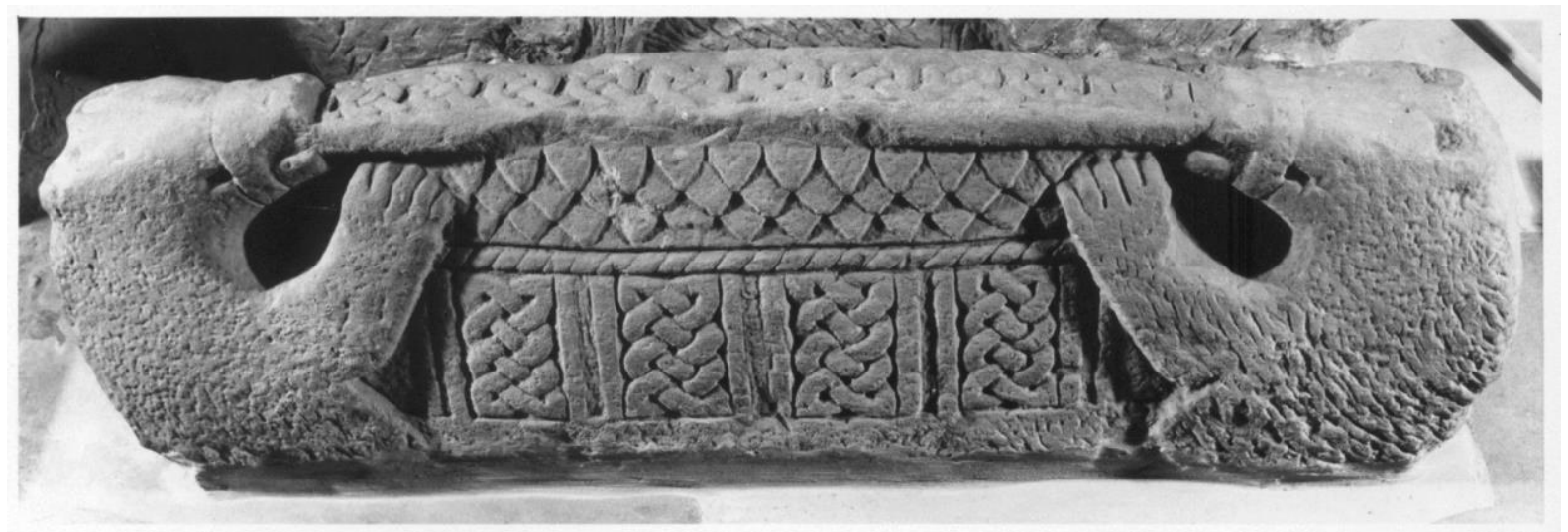

Fig. 9.2 Type a hogback, Brompton 17A (Lang 2001, plate 82).

The earliest monuments are traditionally dated to the second and third quarters of the tenth century on stylistic grounds and similarities have been identified between the 'roofs' on some hogbacks and tenth-century buildings from southern Scandinavia (Schmidt 1973). However, precise historical parameters cannot be reliably imposed on the beginnings or the ends of either the production or the use of hogbacks without recourse to circular argumentation relating to the Hiberno-Norse diaspora. Lang warns against equating their typology with their chronology but was probably correct to assume that the hogbacks with muzzled beasts of Allertonshire (North Yorkshire) were among the earliest (Lang 1984, 97). He argued that the naturalistic bears rapidly becoming more dragonesque, stylized and vestigial with time (Lang 1984, 95). Therefore, Brompton has been considered the most likely place of origin for the hogback monument because the site has produced eleven high-quality monuments, but this is by no means certain (Lang 2001, 47; Figs 9.2, 9.3 and 9.4). Meanwhile, other foci of the monument are Sockburn-on-Tees (nine monuments) and Lythe (seventeen monuments). These three sites, together with York, constitute a core of the hogbacks' use during the course of the tenth century and possibly beyond. 

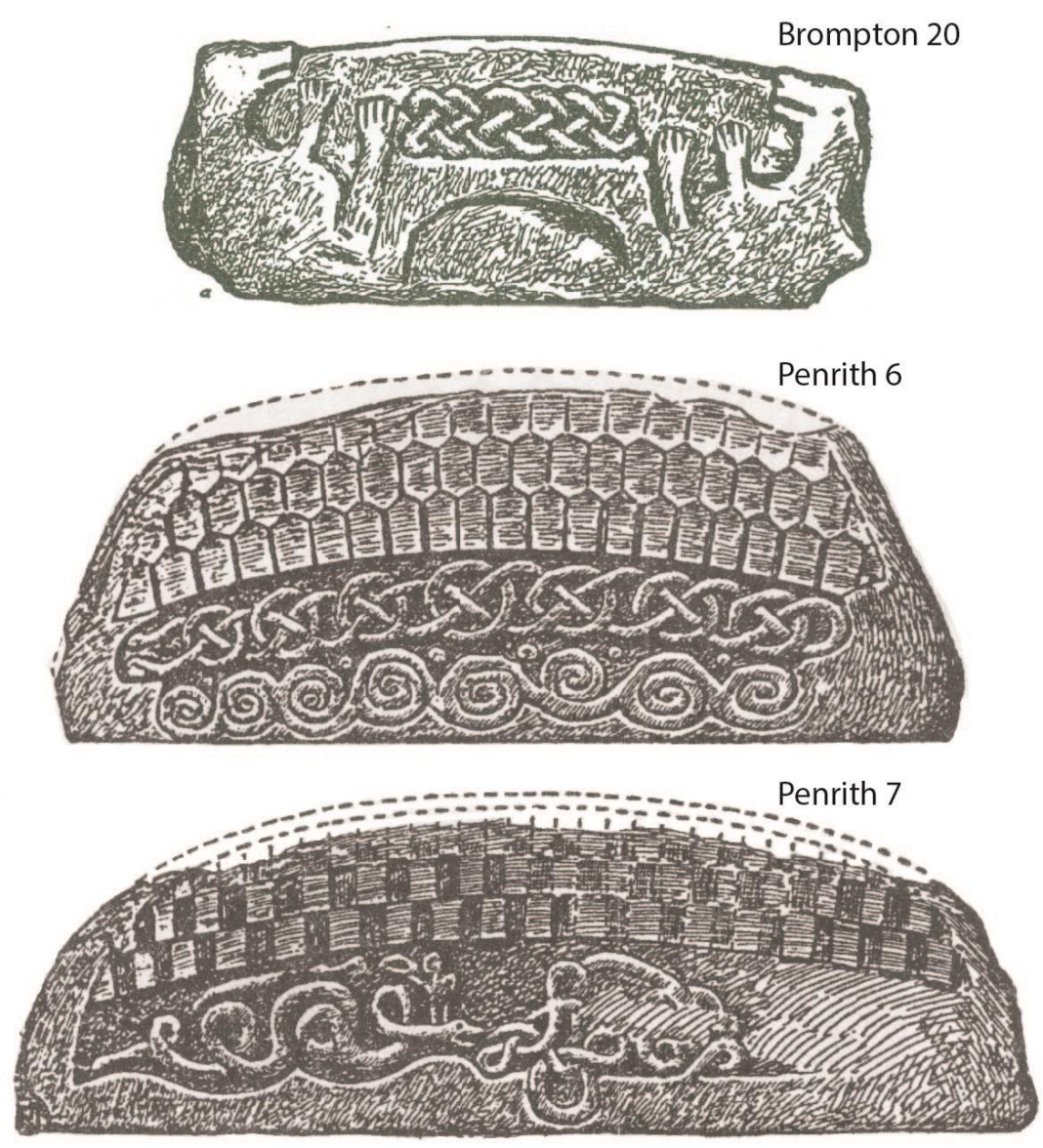

Fig. 9.3 Composite of illustrations by W. G. Collingwood of hogbacks from (top to bottom) Brompton, type d (North Yorkshire), and Penrith, Cumbria, types h (Penrith 6) and g (Penrith 7). While some details of Collingwood's illustrations are problematic and interpretative, his images remain a valuable resource for communicating the varied size and character of the monuments. Scale is approximate.

East of the Pennines hogbacks are therefore primarily distributed in North Yorkshire with a few outliers elsewhere in West and East Yorkshire. To the west of the Pennines, hogbacks are known in coastal Cumbria and the Eden Valley, with outliers in Lancashire and the Wirral peninsula, and are less precisely dated and might extend into the eleventh century. All these areas reflect, in broad terms, the place-name, archaeological and historical evidence for some degree of settlement, and certainly of strong maritime connections with, HibernoNorse groups in later Viking Age (Figs 9.3 and 9.4).

Outside these core areas, there is a distinct group of coped stones classed as hogbacks in the Trent Valley, seemingly reflecting a later adoption of the monument by elites in parts of the heartland of the former kingdom of Mercia (Everson and Stocker 1999; Biddle and KjøbyeBiddle 2001; Stocker and Everson 2001). To the north, the southern Scottish hogbacks also appear to reflect the spread of the monument form along maritime networks outside its original core, with a concentration at Govan that might reflect exposure and close interactions between the British kingdom of Strathclyde's 'Govan School' and the Kingdom of York from later tenth century, thus inspiring a longer use of this monument type into the 
eleventh century and possibly later (Lang 1972; 1972-4; 1976; 1984; 1994; Bailey 1980; see also Driscoll et al. 2005; Fig. 9.4). Notwithstanding the problem that some of these 'hogbacks' display only some of the monument form's key characteristics (e.g. Hall 2015), it seems likely that hogbacks were adapted for new contexts as part of commemorative strategies by elite groups with extensive maritime connections. This helps to explain their core distribution but it also helps provide an appreciation of the thin scatter of possible 'hogback' monuments known from elsewhere through these islands, including St Ninian's Isle (Shetland), Kirkwall (Orkney), Castledermot (Co. Kildare), Aberarth (Ceredigion), Winchester (Hants) and Lanivet (Cornwall) (Lang 1971; 1972-4; 1984, 86; Tweddle et al. 1995, 278-80; Edwards 2007, 146-7; Preston-Jones and Okasha 2013, 163-4; Fig. 9.4).

A crucial point in thinking about this distribution and chronology is to take on board the observation by Tweddle et al. $(1995,279)$ that recumbent gravestones with architectural allusions might be the tip of an iceberg comprised of wooden monuments. There are indications that the Christian holy and secular elite early medieval dead over a wider geographical span and a longer chronological duration were commemorated with houseshaped shrines and tombs during the early Middle Ages. The implication is that we need not necessarily seek for a single point of origin for these monuments, or indeed regard them as a singular coherent artefact type. Inspired by multiple sources, Insular and Norse, it remains, however, a distinctive choice to deploy solid stone grave-covers and hence it remains legitimate to explore hogbacks as a varied but significant phenomenon (see also Stocker 2000).

\section{Hogbacks as composite monuments}

Regarding their function, hogbacks are universally presumed to have originally been a form of 'recumbent tombstone' and thus are regarded as part of the church or churchyard environment (Collingwood 1927, 164). However, the obvious limitation to this argument is that no demonstrably in situ hogbacks have been found in their original context over a contemporary grave or graves. One exception is the Winchester monument which might be in situ over a grave (Tweddle et al. 1995). A further possible instance is Heysham (Lancs.) but the account of the hogback's discovery with a skeleton and a spearhead is early and unreliable (Bailey 2010, 201). Likewise, it is unclear whether hogbacks should be viewed as intramural or churchyard monuments. Some appear very fresh and unweathered, but this might have resulted from them being outside but canopied, rather than fully intramural. In any case, the artefact biographies of many hogbacks hint that, as with other stone monuments, their afterlives were punctuated with reuse that sometimes might have constituted a deliberate strategy of forgetting their original commemorative function (see Lang 1984; 1994; cf. Moreland 1999; O'Sullivan 2011). It remains possible that hogbacks were recumbent grave-covers, but they might have equally served as head-stones for a single grave or a group of graves, or were situated away from the graves they commemorated at stations within the church or churchyard. Given their form and character, it is possible that hogbacks might have originally been composed for other contexts and only later displaced to churches and churchyards. However, their form and character and the predominant association with church sites with other sculptural fragments, which together make most sense as components of an ecclesiastical environment, provide strong circumstantial evidence that hogbacks were made for, and installed in, the church or churchyard context. 


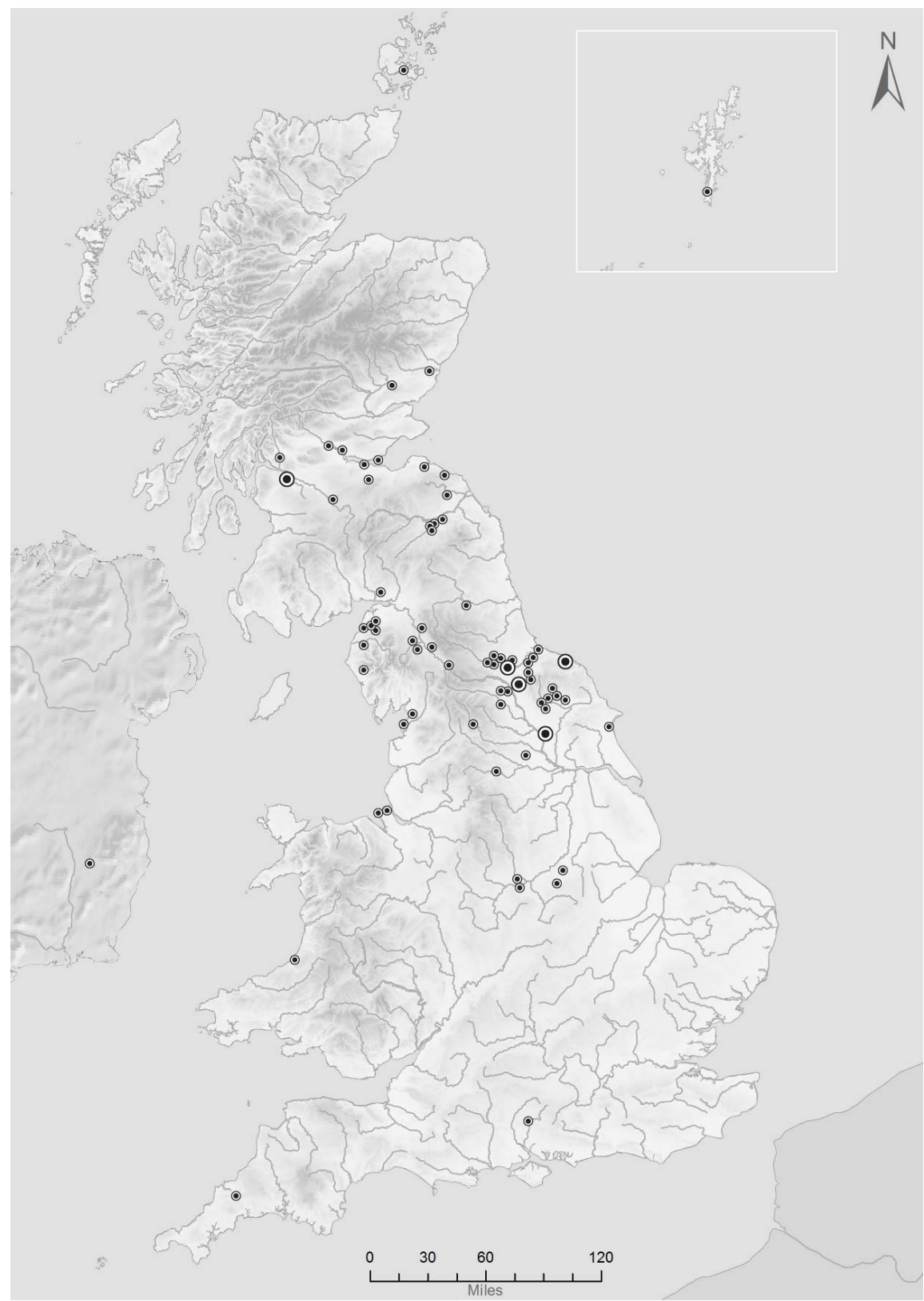

Fig. 9.4 Distribution of sites producing hogbacks (small dots $=1$ or more monuments, large dots $=5$ or more monuments). Scottish 'kindred monuments' and other coped grave-covers of likely late eleventh and twelfth-century date are omitted.

The possibility that some monuments were originally composite monuments - or at least a close connection with crosses (whether marking a single grave or a burial plot) - is suggested by their association with stone crosses of comparable ornamentation and date at Gosforth, Penrith, Aspatria and Brompton. Moreover, hogbacks are usually far shorter, and narrower, than a full grave's length. The latter point is well-made in Figure 9.2, where the Brompton hogbacks are usually under $1.5 \mathrm{~m}$ in length in comparison with the larger Penrith monuments. Therefore, the frequent lack of overt Christian associations in hogback decoration might be deceptive, caused by post-construction disassociation (perhaps from as early as the eleventh century) of the hogbacks from crosses that may have frequently formed an integral part of their design. 
Although it remains different to substantiate with certainty, we might regard some hogbacks as the most enduring centrepiece of composite mortuary monuments made up of perhaps two or three sculpted stones or, alternatively, as the stone centre-pieces originally framed by elements composed of other materials including cloth, leather, wood and both base and precious metals. It is even possible that hogbacks were once covered with tent-like canopies that have failed to survive.

Some antiquarian reports, while not fully reliable, support the composite view of hogbacks. Early records from Inchholm in the Firth of Forth, Scotland, suggest that they were associated with a standing cross in the sixteenth century (Lang 1976, 209). Lang refers to an antiquarian tradition at Gosforth (Cumbria) of hogbacks associated with upright stones (Lang 1984, 97) and the collection of four hogback monuments and two crosses together called the 'Giant's Grave' at Penrith (Cumbria) may allude to an earlier composite configuration, but it is highly unlikely that these preserve original arrangements at either site (see Bailey 1980, 99-100; Lang 1984, 96, 156-7).

Likewise, assemblages of stones discovered from the same location also suggest that hogbacks were composite monuments. At Lythe (North Yorks.), the type i hogbacks lacked gable-end decoration and there are eight stumpy 'grave-marker' crosses with small crosses from the site which match the hogbacks closely in execution and likely date (Lythe 8-16). While it is possible that crosses and recumbent grave-covers were simply alternative and contemporary commemorative media, marking different households, social groups or genders, there is a case to be made that each recumbent monument was originally flanked by crosses or each had a cross at one end (Lang 1994, 129; 2001, 157-9). At Brompton, the surviving crosses have matching interlace with some of the hogbacks and were broadly contemporary if not associated with the hogbacks (Collingwood 1927, 144; Lang 1984, 97; 2001, 65-6; Figs 9.2 and 9.5). Moreover, the short cross-shaft known as Brompton 1 (Lang 2001,65 ) is blank near its base, perhaps to accommodate a hogback in that position (Fig. 9.5). Similarly, while cut back at one end (B), the hogback Burnstall 11 may well have been originally framed by the contemporaneous crosses found at the same site (Coatsworth 2008, 113).

This composite argument might not work for all hogbacks, however. The Gosforth 4 and 5 (Bailey and Cramp 1988) are relatively rare in having figural inscribed end-panels, showing that a minority of hogbacks were demonstrably not designed for arrangement with endcrosses (Fig. 9.7). However, not only are these exceptional, they do indicate the Christian affiliations of the monuments and their probable framing by Christian apotropaic scenes, as with the late ninth-century house-shaped tomb cover Dewsbury 15 with cross-inscribed gable-ends; this monument might be regarded as a proto-hogback (Coatsworth 2008, 1478). Likewise, the possible Norse mythological scene on the gable-end of York Minster 46 (Lang 1991, 77-8) and Bedale 6B (Lang 2001, 61-2) show that hogbacks could operate as stand-alone monuments, but perhaps in these instances other components, such as crosses, stood some distance from, but not fully disassociated from, their ends. 


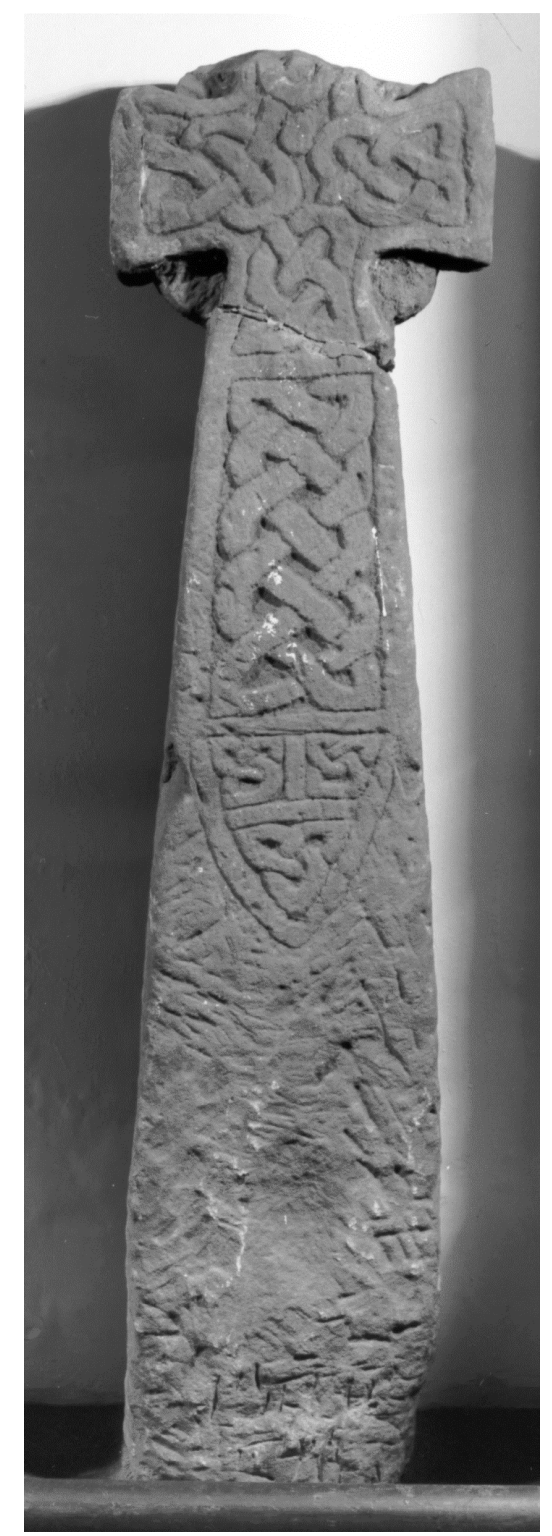

Fig. 9.5 Brompton cross 1A (Lang 2001, plate 30).

Further support for the argument that hogbacks could be central elements of composite monuments is found by analogy with the head and foot-stones associated with the gravecovers from York Minster, although admittedly these are stones of tenth-century date reused in the eleventh century (Lang 1972-4, 211; 1984, 97; 2001, 49). An additional analogy arises from the work of Everson and Stocker, who have argued that mid-Kesteven gravecovers were never decorated at either end because they may have often been framed by crosses, a view supported by surviving composite monuments (as with the Lincolnshire monuments Cranwell 1 and 2 and possibly also from Burton Pedwardine: Everson and Stocker 1999, 44).

In summary, while almost all hogback stones were found reused in later church fabric or else situated in secondary contexts within the churchyard with no verification as to their original location, it is clear that hogbacks were certainly a commemorative medium, and sometimes they were parts of composite mortuary monuments flanked by crosses. Still, they need not 
have marked single graves, but might have readily marked burial plots reserved for specific families. However, because they drew on transformations of other materials and things buildings and beasts - that eschewed texts, none bear inscriptions attesting to the motives of those who commissioned or made them, let alone those whom were commemorated.

\section{Hogbacks as corporeal metaphors}

Despite the challenges in understanding the functions of hogbacks, the foundations of their interpretation have been advanced over the last forty years by a small number of influential investigations. Aided by, and contributing towards, the Corpus of Anglo-Saxon Stone Sculpture, studies by Richard Bailey (1980; 1996), James Lang (1971; 1972; 1972-74; 1976; 1984; 1994) and, most recently, Paul Everson and David Stocker (Stocker 2000; Stocker and Everson 2001) have explored hogback monuments in terms of their form, decoration, date, distribution and function. With different degrees of emphasis, most have followed Lang's interpretation that hogbacks are 'colonial', reflecting Scandinavian settlement and these newcomers' mercantile affinities and ideologies, and including some scenes from Norse mythology (Abrams, n.d; Lang 1984; Crawford 1994; Stocker 2000, 195-7; Edwards 2007; Kopár 2012). Having said that, Karkov (2011, 253-5) has recently and rightly emphasized that hogbacks are better described as 'post-colonial', indicative of the interplay between settlers and indigenes conversant in Insular traditions of Christian art. As such, and as Lang and others have already conceded, there are no immediate precedents of stone-carved hallshaped structures known from pre-Christian Scandinavia and hogbacks operated within, and spoke to, Christian audiences (e.g. Bailey 1980). Richard Bailey has rightly described them as: 'an insular art form being pursued with such enthusiasm in the new Anglo-Scandinavian north' (Bailey 1996, 80), and hence the medium of stone and the mortuary context of their use reveal long-standing Christian influences. Moreover, while the Scandinavian mythological elements of northern English Viking-Age sculpture have received most attention (most recently, Kopár 2012), they remain rare in the full corpus of hogbacks. Furthermore, Bailey emphasized that much of the sculpture retains traditional Christian symbolism and iconography from the vine scroll to the crucifixion. Indeed, many of the interlace designs and other abstract patterns upon hogbacks were of Insular origin (Bailey 1980; 1996, 81-2). David Stocker (2000) has retained an association with Norse groups, but rightly connects hogbacks with churches upon wealthy estates linked to principal road and river networks, whether new foundations or re-foundations of pre-existing churches. Hogbacks were thus an active means of consolidating and commemorating elite power (Abrams 2000, 139-43; Hadley 2000, 119). In his view, hogbacks drew upon pagan motifs to articulate the act of religious conversion to Christianity with the building being suckled by bears as a metaphor for salvation through the Church.

Hogbacks were almost certainly innovative products of a socio-political and religious hybrid commemorative environment associated with the new networks and socio-political context of the later Viking Age in which the scale and range of stone sculpture increases immensely. Hadley's (2008) exploration of the sculptural representation of martial elite masculinity in the tenth-century northern Danelaw offers an invaluable context. Hadley only tangentially addresses hogbacks, noting their inherent multi-vocality (Hadley 2008, 278) and how they might have commemorated kin-groups and households, not simply elite males (Hadley 2006, 260-61; 2008, 280). Moreover, hogbacks might be seen in relation to her discussion of hegemonic masculinity (see also Gilchrist 2009) at a time of socio-politic flux, not because 
they were exclusively 'masculine' monuments but because they probably asserted the claims to lordship and its inheritance and legitimization of martial elites in which men and womenfolk were key agents. What is important is that, while hogbacks emphasize beastly bodies and architecture in tension, their subject is clearly the protection and mortuary transformation of select human cadavers.

It is in this regard that we can extend the importance of Thompson's (2004) exploration of later Anglo-Saxon vernacular literature and the varied role of wyrmas in relation to corpses. While largely avoiding hogback monuments, her interpretation of grave-slabs from York and cross-shafts from Masham (North Yorkshire) and Middleton (East Yorkshire) foregrounds the varied representations and multi-vocal power of beastly serpentine guardians in mediating the transformations associated with the death, burial and rebirth of the body and soul in a Christian theological and cultural environment. Significantly for the discussion of hogbacks, Thompson emphasizes how different kinds of beastly form (including snakes and winged serpents), and different types of human body - both martial and seemingly without weapons and perhaps unclothed - can be employed in relation to wyrmas to articulate the fate of body and soul and hence punctuate the transformation and commemoration of the dead (Thompson 2004, 132-69).

In combination, the work of Stocker, Hadley and Thompson together reveals important insights into how we consider hogbacks as active statements of elite identity in death in Viking-Age northern Britain. Certainly many hogbacks (especially types $b$, e and $f$ ) materialize buildings framed by dragonesque beasts which can be readily interpreted as comparable to Thompson's literary and sculptural wyrmas. Yet the broad themes of mythological conflict as integral to Norse pagan worldviews which sometimes appear on the stones (see Kopár 2012) and the specific links between bears and Viking warrior cultures (e.g. Price 2002) might suggest that end-beasts, including bears, were a distinctive way of articulating the aspired fate of the body and soul upon death. The Christian symbolic associations of bears, including their association with rebirth from hibernation and the belief that bears licked their bodies into life (Stocker 2000), extend the multi-vocality of these beasts as aggressive forces tamed by faith. Likewise, bears' hibernatory and thus subterranean associations make them another powerful metaphor for death and promised resurrection. As powerful wild animals with mythological and legendary associations, bears, like wolves, can be considered as spanning early medieval pagan and Christian imagination and material culture (see Pluskowski 2006).

It is evident, therefore, that hogbacks would have been an apotropaic and transformative medium with which to commemorate the dead, a mnemonic strategy which may have spoken to pagan, converting and multi-faith audiences, but they are indisputably compatible with Christian thinking about death and the afterlife. Hence, as with Viking-period furnished graves dated to the later ninth and tenth centuries elsewhere in Britain and Ireland, we should not assume all those deploying hogbacks were of Scandinavian descent or affinity (Halsall 2000). Equally, it is important not to explain away their secular resonances. Furthermore, the locally diverse and changing nature of hogbacks suggests no correlation to a single religious and socio-political process. Instead, hogbacks are better seen as taking on varying manifestations and contexts of deployment in and around ecclesiastical settings. For example, while in their heartland, they might have communicated messages of elite dynastic 
claims to the inheritance of land and power as well as to shared Hiberno-Norse identities and origin myths, for later generations and in areas away from their core use, as in Lincolnshire (Everson and Stocker 1999; see also Stocker 2000; Stocker and Everson 2001), Wirral (Bailey 2010; Bailey and Whalley 2006) and southern Scotland (Lang 1994), these monuments may have reflected and asserted different socio-political allegiances and perhaps even a shared resistance to West Saxon hegemony experienced by much of northern Britain during the course of the tenth century (cf. Sidebottom 1999; 2000).

The selectivity with which hogbacks were used is evident even in the heartland of their occurrence, suggesting this was a monumental form selected only by some. Hence, while Brompton in the Vale of York has eleven hogback monuments, in nearby sites where sculpture of the 'Brompton School' has been recognized none have been found (Lang 2001, 47). Strikingly, there are few in West Yorkshire despite many sites yielding sculpture of the period (Coatsworth 2008, 36) and, likewise, few are found north of the Tees and none from the Isle of Man (Lang 1984, 87-90). The hogback monuments' discrete distribution therefore conceals their rhizomic rather than dendritic adoption as a commemorative medium: they crop up stemming from unseen networks of influences and ideas in discrete clusters and yet are absent in other sites close by that have produced contemporary sculpture.

\section{Hogbacks as skeuomorphic citations}

This study has shown how previous work has addressed coherently the date and distribution, iconography and ornament of hogbacks. However, what has been lacking thus far has been attention to the materiality of hogbacks created by their skeuomorphic citations to beasts, wood, textile and other materials and substances. As mentioned above, the architectural form (curved walls and curved roof) of many hogback stones resonates with contemporary bow-sided halls known from Scandinavia (Collingwood 1927, 164; Lang 1976; 1984; 2001; Bailey 1980, 86-7; 1996; Bailey and Cramp 1988; Cramp 1988; Schmidt 1973; 2007). Ornamentation supports their house-like design, with sculpted tegulated roofs adorning some examples.

However, other elements of their design find an origin not in contemporary house-designs but in early Christian metal house-shaped reliquaries that so often have beasts surmounting the gable ends (Youngs 1989, 134-40). Moreover, there are church/building-shaped caps on early medieval Irish crosses (Bailey 1980, 92; Lang 1972-74, 206). Both crosses and reliquaries demonstrate the prevalence of the house-form in contemporary religious monuments and mobilary art and artefacts. This range of associations challenges our desire to identify a single, exclusive inspiration for hogbacks from contemporary wooden secular architecture. Indeed, while none survive, we surely have to imagine that a tenth-century timber church could have been constructed in a comparable fashion to a lord's hall, reflecting the interplay between their functions and the symbolism of places of protected, public gathering.

Perhaps the closest parallels for hogback monuments are indeed commemorative monuments such as the house-shaped shrines from early medieval Britain and Ireland (e.g. Herity 1993), including the composite and hollow Northumbrian shrine from Jedburgh (Scottish Borders; Bailey 1980, 96). Closer still, Hedda's Tomb, Peterborough (Cambs.), and Bakewell (Derbys.) are seen as the closest solid stone shrines, yet there are hints that examples may have once been present in northern England. For instance, Bailey regards 
Oswaldkirk 2 and Sinnington (both North Yorks.) as examples of solid Anglian (i.e. eighth- or ninth-century) shrines (Bailey 1980, 96), although Lang recognizes only Oswaldkirk 2 and notes its uncertain date and fragmentary survival (Lang 1991, 198). Coatsworth $(2008,38)$ assigns the now-lost Leeds 8 monument (West Yorks.) as a shrine-tomb fragment and suggests that Dewsbury 15 (West Yorks.) - regarded by Lang $(1984,130)$ as a hogback might be a pre-Viking (possibly late ninth-century) shrine-tomb and hence a precursor to the hogbacks (Coatsworth 2008, 38; 148). Yet again, however, this monument is not indisputably pre-Viking in date. We do have to entertain the possibility that other house-shaped architectures were deployed in Viking-Age mortuary practice, including biers and temporary tents covering graves in addition to tombs themselves.

Lang $(1984,95)$ sums up these many potential influences on hogbacks by foregrounding the enchained relationship between skeuomorphic translations. He does this by regarding hogbacks as 'a skeuomorph of a skeuomorph: a grave-cover designed as a casket which is in turn based on a building' (Lang 1984, 95). However, we might dispute the precise character and exclusivity of this chain of influence. Still, the key point is that the subtle nature of his argument is often lost on later commentators, who presume a direct translation from fullsized wooden churches and halls to hogbacks and predicate their interpretations on this relationship between hogbacks and full-sized buildings (e.g. Stocker 2000). Lang also goes on to suggest that the arrangement of recumbent slab with head and foot stones found in excavations at York Minster might provide the inspiration for the hogback design (Lang 1984, 96). Rather than a conclusive indication of origins (or a sequence of origins and inspirations which is far more likely) on monument design from a single source, Lang's crucial interpretation can be more profitably framed as a network of interconnected materialities spanning both Insular and Viking worlds and their zones of intersection. Clearly, hogbacks received both multiple and successive influences from both secular and religious materials and architectures of Insular and Scandinavian origin. Rather than simply being 'miniatures', hogbacks were simultaneously related through an array of citations, operating as miniatures, gigantisms and broadly same-size material cultures. Hence, hogbacks would have been encountered by those familiar with a range of materials and buildings employing architectural forms. Rather than citing 'the aristocratic hall' exclusively, hogbacks simultaneously cited tents, canopies, biers, caskets, crosses, churches, shrines and tombs that together comprised an architectural understanding of the cosmos, society, the body and the tomb.

Regardless of the precise balance of influences upon the design of individual hogbacks, which as we have seen are, in any case, extremely varied in form and ornament, it is more profitable to recognise how these influences gained significance through translation and incorporation into the hogback's materiality. In stark contrast to Lang (1984), who regards the skeuomorphism of hogbacks as not to be taken too seriously, I regard the skeuomorphic character of hogbacks as central to their commemorative significance in protecting and transforming the dead. As an active commemorative strategy, rather than simply a result of passive influence, skeuomorphic allusions connected hogbacks to a wide range of other materials and substances and the contexts in which they were experienced and used. Hogbacks adopted and adapted pre-existing material motifs and forms from a range of commemorative media and distilled them into a new materiality. Thus, hogbacks were a mnemonic tool for enchaining people and things by drawing upon the associations and 
significations of these other architectures, material cultures and ornamentations. Hogbacks from this perspective can be regarded as making citations to a range of high-status architectures and material cultures in the mortuary arena. Hence, alongside the reuse of earlier tombs as a commemorative strategy (e.g. Rawlin-Cushing 2011), tenth-century tombs were condensing citations from a range of existing media, distilling them into a new solid form and taking on their power through the act of material transformation.

This approach has been previously applied to the sequence of citations made between burial events in early medieval cemeteries (Williams 2006, 61-5) and draws from Hawkes's (2003) agenda to explore the multi-media qualities of early medieval stone sculpture and the range of materials they related to (see also Williams 2011). Thus, hogbacks can be theorized as a technological choice of material and form and as strategic skeuomorphism. These themes operated within a 'technology of remembrance' (Jones 2007; Williams 2006), projecting and constituting a distinctive vision of the dead and their identities in relation to a variegated constituency of survivors. In this context, hogbacks can be regarded as constituting and commemorating social status and identity and social memories of either de novo dynasties or established elites reformulating their identities within a new socio-political context. In either scenario, yet specifically, they were effective as technologies of remembrance because they afforded the dead body with a tangible materiality within an implied but solid architectural space.

In summary, rather than following Lang, who sees hogbacks' architectural references as 'purely decorative' (Lang 1984, 93), their non-functional skeuomorphic nature made them powerful mnemonic devices. Hogbacks thus cited the idea of the tomb as an inhabited space, protected by faith and exhibiting martial power and authority through allusions to halls, churches, saints' shrines and a wide range of other elite material cultures and buildings. As such, hogbacks operated to legitimize exclusive imagined pasts, claims in the present and aspirations for the future for elites establishing and consolidating, or else refashioning, their identities during mortuary practice (Lang 1984, 89-90; Hadley 2008).

\section{Hogbacks as solid spaces}

Exploring the skeuomorphic citations of hogbacks is, therefore, an important avenue for investigating the commemorative power of the materiality of hogbacks and thus appreciating how specific monuments operated distinctively and individually as well as as emergent cumulative assemblages at specific locales.

The remainder of this paper takes forward the different ways in which the skeuomorphism of hogbacks, as well as their weight and size, created distinctive interplays between beasts, apertures and solidity. Together these dimensions relate to the mnemonic ramifications in creating the illusion of an inhabited architectural space within a solid block of stone. As Devlin (2011) discusses for other kinds of early medieval stone sculpture, whether covering single graves or burial plots, hogbacks singly and in combination created a powerful presence within the commemorative topography of tenth- and eleventh-century churchyards, whether newly founded sites or long-established Christian loci, as exemplified by sites such as Heysham (Lancs.) (Potter and Andrews 2004; Bailey 2010; Nash 2010). Rather than offering a focus of healing and worship in these environments, as with the tumba of St Chad 
described by Bede, hogbacks materialized inhabited space yet also protected and closed off physical access to the dead.

Spaces within the solid architectural form are implied first and foremost by the hall-shaped form, but also by its indivisible and weighty solidity. Moreover, for those hogbacks with endbeasts, the gable-ends where end-doors and smoke-holes would have provided ventilation and access to contemporary buildings are literally stopped by the gripping beasts. Therefore, the animals further emphasize the 'closing' and sealing of the apertures of the architectural space. The closed mouths of the bears and grip of their paws fix and protect the lithic architecture in place (Fig. 9.6). Lang $(1984,103)$ refers to the horror vacui of hogbacks leading to 'density (even clutter) of design and a tendency to cover the surface to the maximum of ornament'. A palpable set of exceptions, which might imply apertures through lack of decoration, are the spaces between the forearms and muzzles of bears, as upon Ingleby Arncliffe 4A and Brompton 25 (Lang 2001, plates 104-6, 335-6).

Hogbacks' ridges and roofs are by definition tangible and sturdy yet simultaneously imply permeability and the potential for access into and movement out of their cracks, corners and surfaces. Wooden shingle roofs fit this category themselves, but so might the diamonded roof of Gosforth 5 (Fig. 9.7). This is an elaborate hogback and its simple decorated roof has been taken to reflect poor-quality work. However, rather than regarding this hogback as bearing a poor rendition of a shingle roof, instead, with its plait surround, we could consider it as a skeuomorphic representation of a leather, textile or other semi-permeable surface of organic material (Bailey and Cramp 1988). Another example of permeable roofing is Aspatria $6 \mathrm{~A}$ (Fig. 9.8), where the type 9 tegulation, each uniquely bearing triquetra patterns, has large arch-shaped gaps in between that are potentially to be considered as a series of apertures into the space within (Bailey and Cramp 1988, 53-4, plate 35). Rather than simply a tegulated roof, are we here seeing instead a depiction of the multiple apertures of a church clerestory, screen or shrine? Indeed, triangular windows are a well-known feature of later Anglo-Saxon architecture in both stone and wood (e.g. Ayre and Wroe-Brown 2015). The same point applies for the large type 2 tegulae on Crathorne 5 (Lang 2001, 86-7).

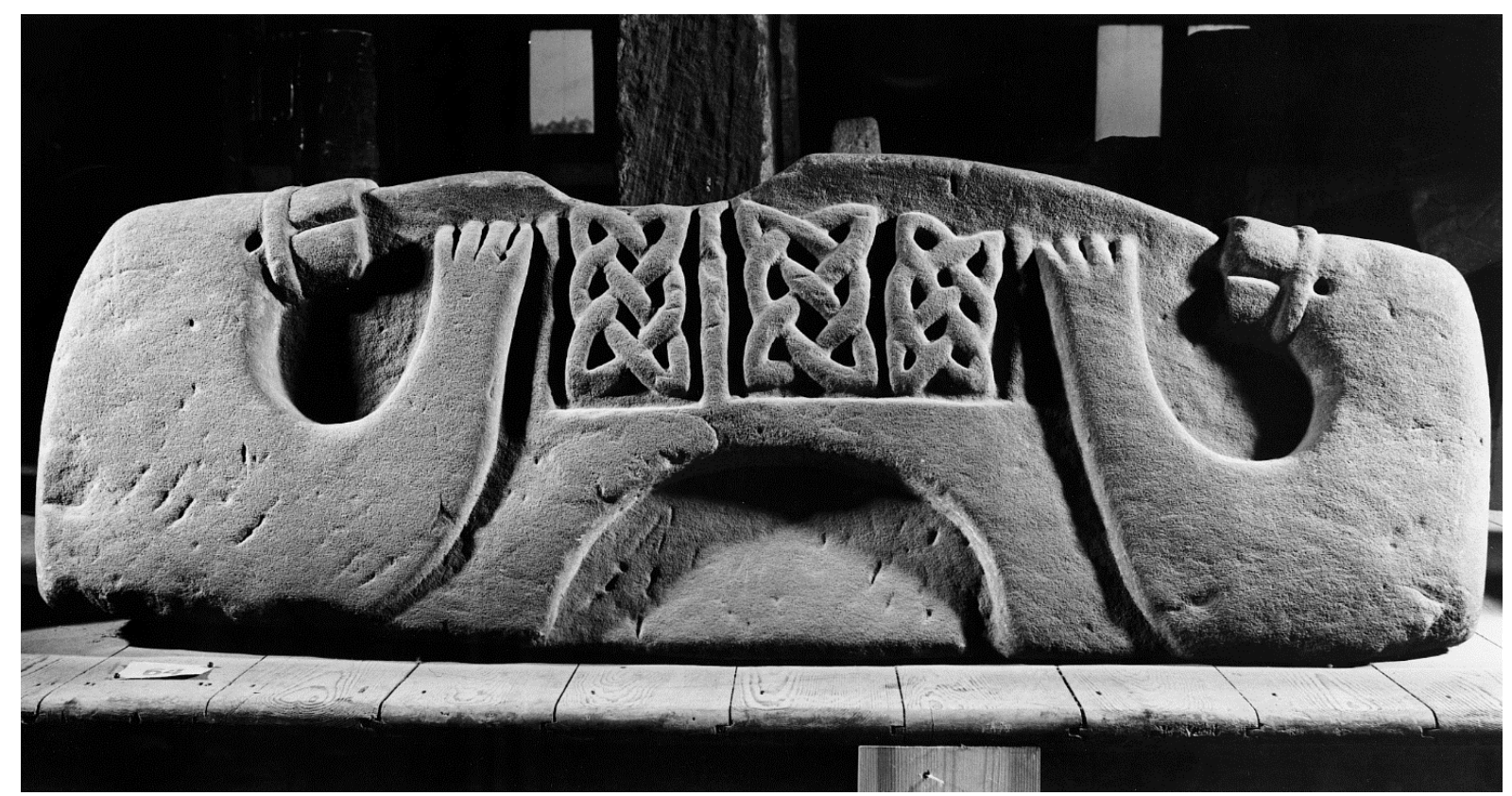


Fig. 9.6 Type c hogback, Ingleby Arncliffe 4A (Lang 2001, plate 335).

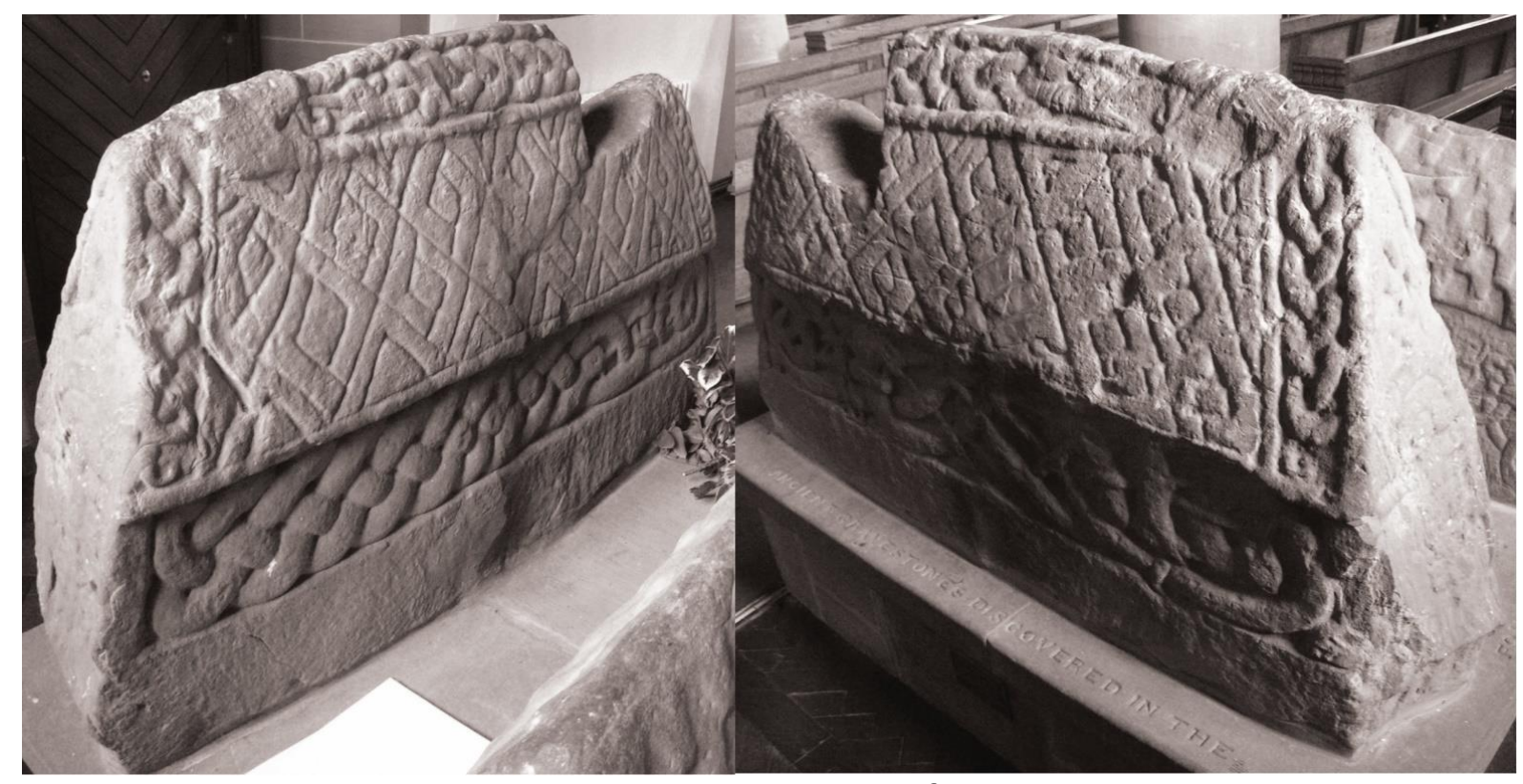

Fig. 9.7 Type k hogback Gosforth 5 .

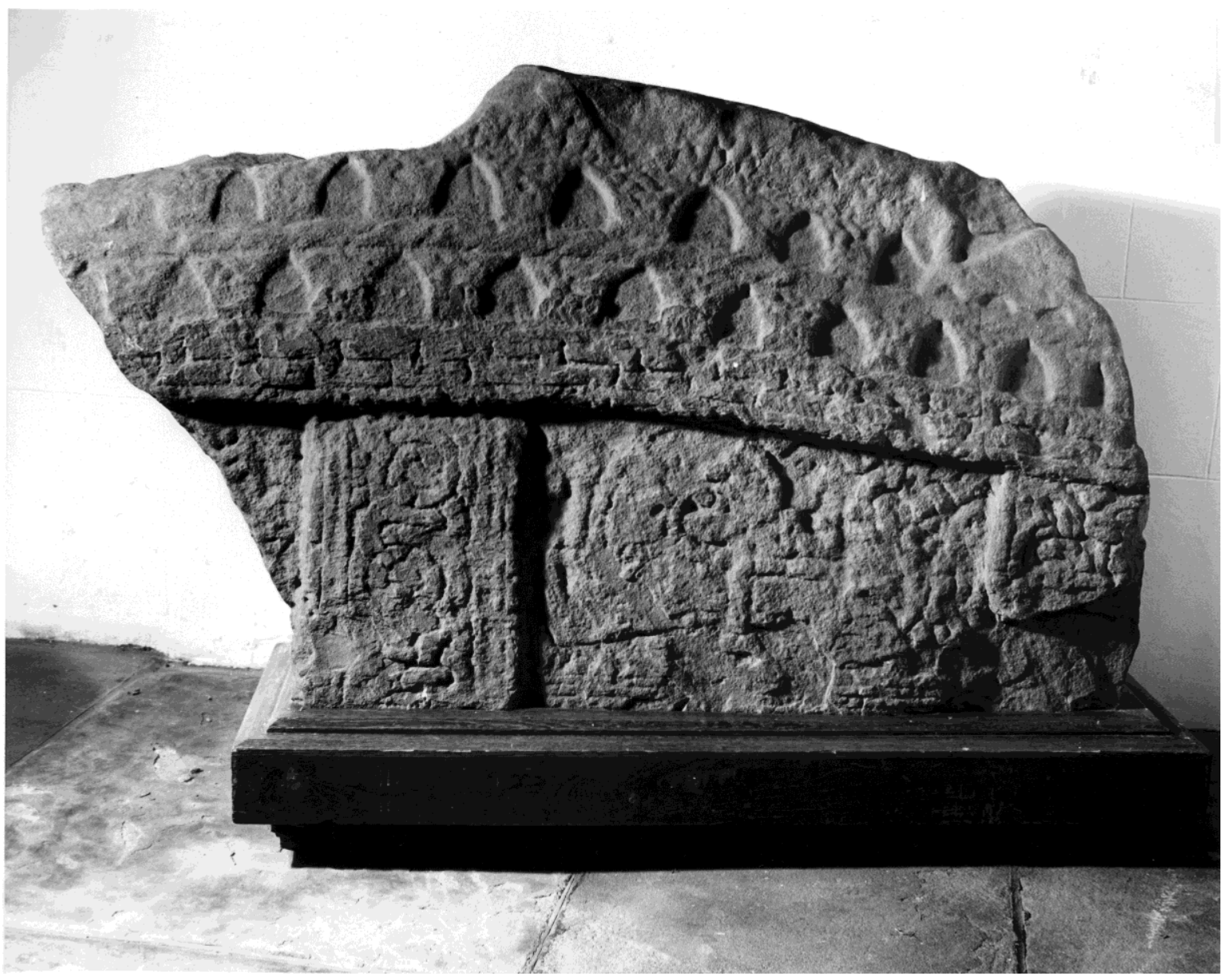

Fig. 9.8 Type b hogback, Aspatria 6A (Bailey and Cramp 1988, plate 35). 


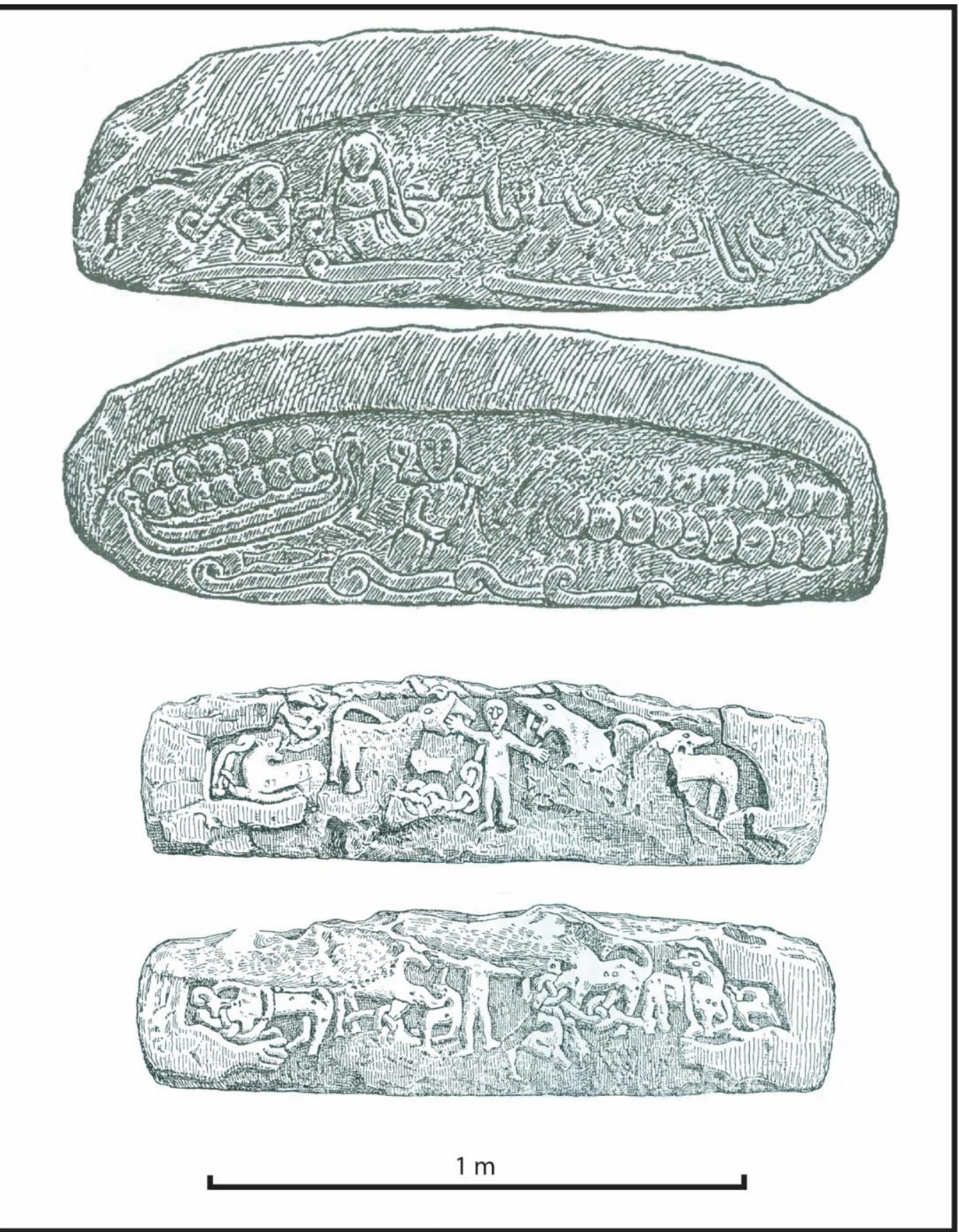

Fig. 9.9 Type g hogbacks from Lowther 4 and Sockburn 21.

It is evident that the architectural inspirations and material forms of many hogbacks imply permeable canopies or roofs guarded by end-beasts when present. Hogback sides often explicitly allude to permeability in a range of fashions. Lang's $(1984,98)$ types c and d - 'niche' and 'extended niche' - are particularly powerful in this regard. For example, Brompton 16, 20 and 22 (Lang 2001, 73-4; 76-7; Fig 9.3), Ingleby Arncliffe 4 (Lang 2001, 126; Fig. 9.6) and Sockburn 17 (Cramp 1984b, 141-2) each afforded arched niches that lead into inaccessible solid spaces. We might speculate as to whether these niches, as with the illustrative panel hogbacks (see below), once contained portraits of the dead or mythological scenes. It is important to remember that, in these examples, roofs are not depicted at all. Instead, the structure is comprised of a curving ridge and it is possible that, rather than skeuomorphic of a house primarily, these ridges allude to canopies covering biers for the conveyance of the 
corpse, tents utilised to cover the open grave and/or tent-like canopied tombs and shrines within churches and chapels. Allusions to permeable apertures on the sides of hogbacks are not restricted to the niche and extended-niche type hogbacks. It might be tempting to see the vertical panels of plaitwork and interlace on the sides of type $a$ and $b$ hogback tombs, like Brompton 17 (Fig. 9.2), 18 and 23 and Aspatria 6 (Fig. 9.8), as purely decorative infill in contrast to the skeuomorphic roof sections. An alternative view might be to see these as vertical hangings of leather, wood or embroidered textile whose presence as a surface simultaneously implies an accessible space within, like the curtain or curtains implied by the former presence of a railing that might once have covered the images of saints on the Hedda Stone from Peterborough Cathedral (see above).
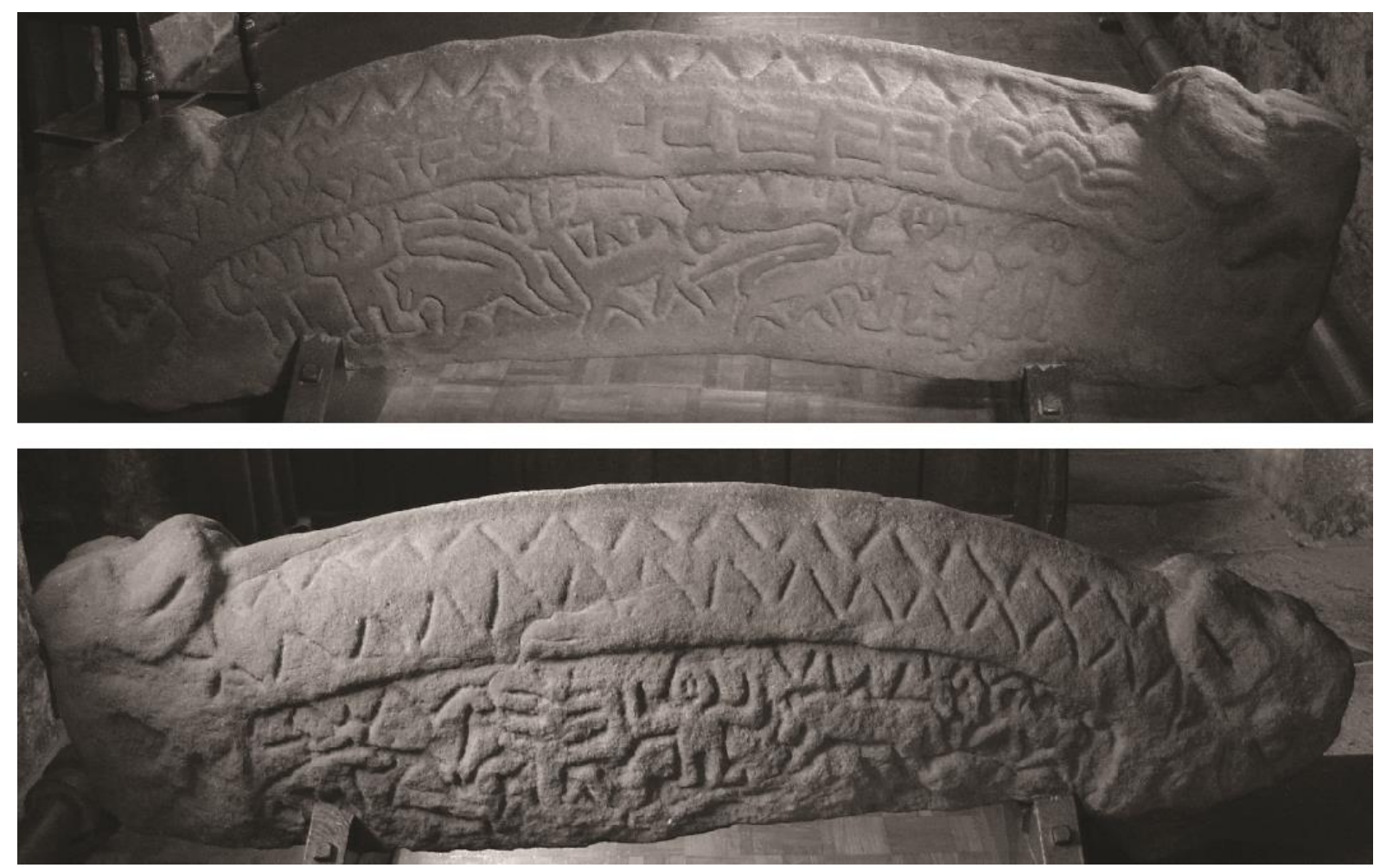

Fig. 9.10 Type g hogback from Heysham.

The horizontal panels of scroll and plait upon type h hogbacks, as with Gainford 22 (Cramp 1984b, 87-8) and Penrith 6 (Fig. 9.3), just like those upon type b hogbacks, might be further allusions to textile or other permeable materials. Type $g$ hogbacks, with their illustrative panels, might be further manifestations of this theme. Whether considering examples such as the Lowther 4,5 and 6 hogbacks, with human figures of uncertain identity and confronting armies (Bailey and Cramp 1988), Sockburn 21 with its possible representation of Tŷr and Fenrir (Lang 1972; Cramp 1984b, 143-4) (Fig. 9.9), or the Heysham hogback with scenes quite possibly from the legend of Sigurd (Ewing 2003, Bailey 2010, 201-4) (Fig. 9.10), these type g hogbacks might be regarded as providing visions of mythological narratives involving human conflicts with monsters, evoking pasts to be honoured and remembered and/or visions into subterranean realms and the trials that the souls of the dead must navigate.

If so, these hogbacks are as much portals as buildings and only type $i$ and type $\mathrm{j}$ hogbacks remain without implied permeability. Rather than attempting to force the variability of hogback stones into the same theme, it might be appropriate to accept that there are 
different commemorative strategies at work here. For some hogbacks, the solidity and inaccessibility of the structure is clear, while for others allusions to implied and represented apertures are more evident. Still, we have identified here a clear theme of spatial solidity and implied but denied accessibility as an important dimension to the design of many hogback tombs.

Together, these allusions to solid space may have been powerful in creating a sense of hogbacks as protective and yet also intercessory loci between the living and the dead: secular equivalents to saints' shrines as loci resurrectionis (Ni Ghrádaigh and Mullins 2013). This is not as speculative as it might at first sound. After all, one of the contended meanings of the shape of Gotlandic picture stones is a doorway (Andrén 1993; Nylén and Lamm 1988) and Thompson (2004) argues the same for some late Anglo-Saxon Cambridgeshire grave-slabs. From this perspective, hogbacks were 'doorways into other worlds' as much as a 'house for the dead'. In both senses they were solid spaces into which the living could not travel but where the dead who inhabit them were perceptible, implied and perhaps also communicated with and prayed for: sacred vessels and apertures comparable to the coffins and shrines of saints (Ní Ghrádaigh and Mullins 2013). Hogbacks thus operated as conduits as much as residences, places of sustained dialogues with the dead mirroring broader archaeological traces of thresholds as mortuary portals recently explored by Eriksen (2013) for Viking Age Scandinavia. This need not imply that hogbacks were exclusively linked to pre-Christian Norse worldviews, however, since beast-guarded thresholds have a long precedent in Late Antique and Insular Christian art (e.g. Kitzinger 1993, 4-5).

Setting aside details of ornamentation and form, hogbacks' solidity and weight are in themselves powerful spatial deployments of the scalar and material transformations embodied in the hogback form. For example, the overarching sense of size and weight of the Govan hogbacks has been repeatedly observed (e.g. Bailey 1994), yet is rarely a foregrounded dimension to their significance as commemorative monuments. Linked to this argument are the gestures of the beasts on type a and b hogbacks. In a striking manner unparalleled in early medieval sculpture, hogbacks freeze in three dimensions the temporal act of beasts grasping and bound to the hall - thus emphasizing the protection and integrity of this solidity. Moreover, it reveals the potential of seeing the beasts as not merely intercessors with the thresholds - both doorways and smoke-holes - but also beings able to communicate with those within, breathing, growling and talking into solid space. If so, the tomb as material mediation between the living and the dead is apparent in its form, shape and material.

\section{Discussion}

Hogbacks are here considered first and foremost as solid spaces, commemorative strategies deployed to foreground absent presences and the transformation of the dead. The context for this is significant: the later Anglo-Saxon period was a time when the furnishing and investment in the protection of the body is manifest in elite mortuary practice. The dead were afforded a range of coffins, stones and other grave structures to seal and protect the body. These structures rendered the corpse sealed and prevented it touching and leaking into the surrounding earth. This was a material discourse on protection, care and the inviolate nature of the elite dead (Thompson 2004; Williams 2006; Buckberry 2007; Holloway 2010). Architectural allusions on recumbent stones also constituted a secular play on 
concepts of corporeal presence awaiting resurrection. Likewise, later Anglo-Saxon heroic poetry was obsessed with venturing into perceptible but usually inaccessible spaces, such as the dragon's mound in Beowulf (see Williams 2015). Moreover, in this period gravedisturbance was increasingly common owing to the pressures of population, urbanization and the spatial definition of and competition for premier locations within churchyards (Cherryson 2007). This is witnessed very clearly in the reuse of tenth-century sculpture within eleventh-century graves at York Minster (Lang 1991).

Hogback monuments might be set in a context where mortuary geographyremained complex, with churchyards as only one potential burial location, and numerous factors might lead to the abandonment of burial sites (see Hadley 2000; 2006; Astill 2009; Halsall 2000, 264). Equally, the micro-topography of the cemetery itself rendered it a place of power where clerical, family and broader community agencies interacted in the construction of social memory (Stocker 2000; Stocker and Everson 2001; Williams 2006; Devlin 2011). Against this background, elites attempting to assert their foundation - no matter how shortlived they proved to be - wished to instil a sense of permanence, codifying prospective memories for future generations (Stocker 2000, 180; see also Holtorf 1996). Equally, they may have desired to afford a controlled access to the corporeal remains of the dead and counter attempts by rivals to desecrate and disperse their ancestral tombs. Hogbacks therefore simultaneously afforded solidity and weight to protect graves and impose the dead into the churchyard space.

The apotropaic and place-making qualities of hogbacks also had spiritual dimensions. The late Anglo-Saxon landscape was one of demonized places - a landscape of fear, both supernatural and tangible (Semple $1998 ; 2004$ ). Concern over the fate of the soul and disturbance of the besieged body pervaded, as well as fears of the interred body reanimating to harm the living (see Blair 2009). This might explain the particular social and religious emphasis on weighty grave-covers as conveying genealogical permanence and transtemporality (see also Guttridge 2010; Williams 2011) as well as preventing unsanctioned interventions by the living and demonic forces, and thus unwelcome spiritual dialogues between the living and dead.

Rather than a reflection of a colonial context and a primarily Norse monumentality, hogbacks were an overt elite Christian strategy in corporeal commemoration in a post-colonial context, a medium to convey and conflate myths and legends - many undoubtedly of preChristian origin - in relation to a distinct conception of body and soul. This encouraged the projection of the identities of the deceased and mourners, and more specifically the relationship between the living and the dead, back to myths and legends of origin and future to ensure commemoration through subsequent generations. The relative brevity of this monument's use should not distract us from the strong aspirations of those commissioning them and thus transforming churchyard space. This can be considered a form of prospective memory (see Holtorf 1996); the hogback can be regarded as a mnemonic prompt to narratives about past, present and future focusing on the solid space and an inhabited, animated presence for the dead that it implies (see Williams 2006; also Price 2010). If the complexity of this argument to date is set aside, hogbacks were 'weighty', heavy solid stones that impressed the dead physically into the earth of the churchyard and figuratively into the future. 


\section{Conclusion}

The striking commemorative significance of hogback monuments reveals the potential of foregrounding the materiality of carved stone monuments from the early Middle Ages. In this chapter, I have not dwelt on the process of carving or the texture and colour of the stone or the vivid colours in which these monuments may have originally been painted. Instead, my focus has been upon the probable composite form of hogbacks and their skeuomorphic citations to a range of hall-like architectures and material cultures. It has been argued that there is a tension created between the solidity, weight and integrity of the tomb's materiality and the perceptible apertures and permeable surfaces created by skeuomorphic citations. When imposed on ecclesiastical space as heavy and prominent recumbent monuments within the churchyard - bearing in mind that the widespread use of stone grave covers was an innovation for the tenth century of northern Britain (Stocker 2000) - they were powerful 'art with agency' (Gell 1998), operating as an index of the relationship between commissioners and the commemorated upon public spaces. Through their assertion of solid space framed by bound beasts, these monuments may have legitimized origin myths, ancestry and inheritance by dynasties both new and old within the troubled and shifting socio-economic and political context of northern England in the tenth and early eleventh centuries. This striking and powerful statement by mourners about the dead that resonated both with Scandinavian and Insular aristocratic cultures reflected a 'heroic' ideal of real and imagined pasts (see Bailey 1980, 30) and aspired futures, as well as chiming closely with an overt Christian message concerning the integrity of body and soul awaiting Salvation played out for secular elites. The short-lived nature, rapid adaptation and commonplace reuse of many by the Norman Conquest, if not before, should not distract us from the potential of exploring the interplay between material and space for those commissioning and designing, sculpting and installing, mourning and encountering hogbacks.

\section{Acknowledgements}

This research was supported by the Leverhulme Trust Research Project Grant 'Speaking with the Dead: Histories of Memory in Sacred Space'. Some preliminary ideas for this paper were originally aired in research seminars presented at the University of York in 2000 and the University of Exeter in 2004. I then presented an early version of this paper at the conference Living through the Dead: The Material Culture and Social Context of the Commemoration of the Dead from Antiquity to the Eighteenth Century, held at the University of Sheffield between 25 and 27 May 2006 and organized by Maureen Carroll, Dawn Hadley and Jane Rempel. I thank the organizers and audience of these seminars and conference for their positive response to my ideas. During this long process of writing and rewriting, I am indebted to the following for subsequently discussing ideas and sharing views on early medieval material culture and commemoration related directly to this paper: an anonymous referee for the chapter and the anonymous reader of the book, Lesley Abrams, Steve Ashby, Richard Bailey, Derek Craig, Meggen Gondek, Joanne Kirton, Carl Knappett, Anna Mackenzie, Ruth Nugent, Hilary Paterson, Elizabeth Pierce, Sarah Semple, Sarah Tarlow and Victoria Whitworth. I am grateful to the Corpus of Anglo-Saxon Stone Sculpture for permission to reproduce Figures $9.2,9.5,9.6$ and 9.8 and to Patricia Murrieta-Flores for her work and guidance in the production of Figure $9 \cdot 4$. 


\section{Bibliography}

Abrams, L. 2000. Conversion and assimilation, in D. Hadley and J. D. Richards (eds), Cultures in Contact: Scandinavian Settlement in England in the Ninth and Tenth Centuries, 135-54, Turnhout: Brepols

Abrams, L. n.d. The Problem of the Hogbacks, unpublished draft manuscript

Andrén, A. 1993. Doors to other worlds: Scandinavian death rituals in Gotlandic perspectives, Journal of European Archaeology, 1, 33-56

Astill, G. 2009. Anglo-Saxon attitudes: how should post-AD 700 burials be interpreted? in D. Sayer and H. Williams (eds), Mortuary Practices and Social Identities in the Middle Ages, 22235, Exeter: University of Exeter Press

Ayre, J. and Wroe-Brown, R. 2015. The post-Roman foreshore and the origins of the Late Anglo-Saxon waterfront and dock of ÆEtheldred's Hithe: Excavations at Bull Wharf, City of London, Archaeological Journal, 172, 121-94

Bailey, R. 1980. Viking Age Sculpture in Northern England, London: Collins

Bailey, R. 1994. Govan and Irish Sea sculpture, in A. Ritchie (ed.), Govan and its Early Medieval Sculpture, 113-21, Stroud: Sutton

Bailey, R. 1996. England's Earliest Sculptors, Toronto: Pontifical Institute of Medieval Studies

Bailey, R. 2010. Corpus of Anglo-Saxon Stone Sculpture Volume IX: Cheshire and Lancashire, Oxford: Oxford University Press

Bailey, R. and Cramp, R. 1988. Corpus of Anglo-Saxon Stone Sculpture Volume II: Cumberland, Westmorland and Lancashire North-of-the-Sands, Oxford: Oxford University Press

Bailey, R. N. and Whalley, J. 2006. A miniature Viking-age hogback from the Wirral, Antiquaries Journal, 86, 345-56

Biddle, M. and Kjølbye-Biddle, B. 2001. Repton and the 'great heathen army', 873-4, in J. Graham-Campbell, R. Hall, J. Jesch and D. N. Parsons (eds), Vikings and the Danelaw, 45-96, Oxford: Oxbow

Blair, J. 2009. The dangerous dead in early medieval England, in S. Baxter, C. Karkov, J. L. Nelson and D. Pelteret (eds), Early Medieval Studies in Memory of Patrick Wormald, 539-59, 5, Farnham: Ashgate

Buckberry, J. 2007. On sacred ground: social identity and churchyard burial in Lincolnshire and Yorkshire, C. 700-1100 AD, in S. Semple and H. Williams (eds), Early Medieval Mortuary Practices, Anglo-Saxon Studies in Archaeology and History, 14, 117-29, Oxford: Oxford University School of Archaeology 
Cherryson, A. 2007. Disturbing the dead: urbanisation, the church and the post-burial treatment of human remains in early medieval Wessex, C. 600-1100 AD, in S. Semple and H. Williams (eds), Early Medieval Mortuary Practices, Anglo-Saxon Studies in Archaeology and History, 14, 130-42, Oxford: Oxford University School of Archaeology

Coatsworth, E. 2008. Corpus of Anglo-Saxon Stone Sculpture Volume VIII: Western Yorkshire, Oxford: Oxford University Press

Collingwood, W. G. 1927. Northumbrian Crosses of the Pre-Norman Age, London: Faber and Faber

Cramp, R. 1984a. Grammar of Anglo-Saxon Ornament. A General Introduction to the Corpus of Anglo-Saxon Stone Sculpture, Oxford: Oxford University Press

Cramp, R. 1984b. Corpus of Anglo-Saxon Stone Sculpture Volume I: County Durham and Northumberland, 2 vols, Oxford: Oxford University Press

Cramp, R. 1988. Corpus of Anglo-Saxon Stone Sculpture in England: General Introduction, Oxford: Oxford University Press

Crawford, B. 1994. The 'Norse' background to the Govan hogbacks, in A. Ritchie (ed.), Govan and its Early Medieval Sculpture, 103-12, Stroud: Sutton

Devlin, Z. 2011. Putting memory in its place: sculpture, cemetery topography and commemoration, in M. F. Reed (ed.), New Voices on Early Medieval Sculpture in Britain and Ireland, 32-41, Oxford: British Archaeological Report, British Series, 542

Driscoll, S., O'Grady, O. and Forsyth, K. 2005. The Govan school revisited: searching for meaning in the early medieval sculpture of Strathclyde, in S. Foster and M. Cross (eds), Able Minds and Practised Hands: Scotland's Early Medieval Sculpture in the 21st Century, 135-58, Leeds: Maney

Edwards, N. 2007b. A Corpus of Early Medieval Inscribed Stones and Stone Sculpture in Wales, Volume II, South-West Wales, Cardiff: University of Wales Press

Eriksen, M. H. 2013. Doors to the dead: the power of doorways and thresholds in Viking Age Scandinavia, Archaeological Dialogues, 20(2), 187-214.

Everson, P. and Stocker, D. 1999. Corpus of Anglo-Saxon Stone Sculpture Volume V: Lincolnshire, Oxford: Oxford University Press

Ewing, T. 2003. Understanding the Heysham hogback: a tenth-century sculpted stone monument and its context, Transactions of the Historical Society of Lancashire and Cheshire, CLII, 1-20

Gell, A. 1998. Art and Agency: An Anthropological Theory, Oxford: Oxford University Press. 
Gilchrist, R. 2009. Rethinking later medieval masculinity: the male body in death, in D. Sayer and $\mathrm{H}$. Williams (eds), Mortuary Practices and Social Identities in the Middle Ages, 236-52, Exeter: University of Exeter Press

Guttridge, A. 2010. The depiction of time on the Arch of Constantine, in D. Boric (ed.), Archaeology and Memory, 158-70, Oxford: Oxbow

Hadley, D. 2000. 'Hamlet and the Princes of Denmark': lordship in the Danelaw, c. 860-954, in D. M. Hadley and J. D. Richards (eds), Cultures in Contact: Scandinavian Settlement in England in the Ninth and Tenth Centuries, 107-32, Turnhout: Brepols

Hadley, D. 2006. The Vikings in England: Settlement, Society and Culture, Manchester: Manchester University Press

Hadley, D. 2008. Warriors, heroes and companions: negotiating masculinity in Viking-Age England, in S. Crawford and H. Hamerow (eds), Anglo-Saxon Studies in Archaeology and History, 15, 270-84, Oxford: Oxford University School of Archaeology

Hall, M. 2015. The Meigle stones: a biographical overview, Northern Studies 46: 15-46.

Halsall, G. 2000. The Viking presence in England? The burial evidence reconsidered, in D. M. Hadley and J. D. Richards (eds), Cultures in Contact: Scandinavian Settlement in England in the Ninth and Tenth Centuries, 259-75, Turnhout: Brepols

Hawkes, J. 2003. Reading stone, in C. E. Karkov and F. Orton (eds), Theorizing Anglo-Saxon Stone Sculpture, 5-30, Morgantown: West Virginia University Press

Herity, M. 1993. The forms of the tomb-shrine of the founder saint in Ireland, in R. M. Spearman and J. Higgitt (eds), The Age of Migrating Ideas: Early Medieval Art in Northern Britain and Ireland, 188-95, Edinburgh: National Museums of Scotland

Holloway, J. 2010. Material symbolism and death: charcoal burial in later Anglo-Saxon England, in J. Buckberry and A. Cherryson (eds), Burial in Later Anglo-Saxon England, c. 650$1100 A D, 83-92$, Oxford: Oxbow

Holtorf, C. 1996. Towards a chronology of megaliths: understanding monumental time and cultural memory, Journal of European Archaeology, 4, 119-52

Jones, A. 2007. Memory and Material Culture, Cambridge: Cambridge University Press.

Karkov, C. 2011. The Art of Anglo-Saxon England, Woodbridge: Boydell

Kitzinger, E. 1993. Interlace and icons: form and function in early Insular art, in R. M. Spearman and J. Higgitt (eds), The Age of Migrating Ideas: Early Medieval Art in Northern Britain and Ireland, 3-15, Edinburgh: National Museums of Scotland 
Kopár, L. 2012. Gods and Settlers: The Iconography of Norse Mythology in Anglo-Scandinavian Sculpture, Turnhout: Brepols

Lang, J. 1971. The Castledermot hogback, Journal of the Royal Society of Antiquaries of Ireland, 101(2), 154-8

Lang, J. 1972. Illustrative carving of the Viking Period at Sockburn on Tees, Archaeologia Aeliana, Series 4, 50, 235-48

Lang, J. 1972-74. Hogback monuments in Scotland, Proceedings of the Society of Antiquaries of Scotland, 105, 206-35

Lang, J. 1976. Sigurd and Weland in pre-Conquest carving from northern England, Yorkshire Archaeological Journal, 48, 83-94

Lang, J. 1984. The hogback: a Viking colonial monument, in S. C. Hawkes, J. Campbell and D. Brown (eds), Anglo-Saxon Studies in Archaeology and History, 3, 83-176, Oxford: Oxford University Committee for Archaeology

Lang, J. 1991. Corpus of Anglo-Saxon Stone Sculpture Volume III: York and Eastern Yorkshire, Oxford: Oxford University Press

Lang, J. 1994. The Govan hogbacks: a reappraisal, in A. Ritchie (ed.), Govan and its Early Medieval Sculpture, 123-31, Stroud: Sutton

Lang, J. 2001. Corpus of Anglo-Saxon Stone Sculpture Volume VI: Northern Yorkshire, Oxford: Oxford University Press

Moreland, J. 1999. The world(s) of the cross, World Archaeology, 31(2), 194-213

Nash, G. 2010. Death and memorial in an early medieval ecclesiastical landscape in northwest England: an appraisal of St Patrick's Chapel and St Peter's Church, Heysham, Lancashire, in A. George, D. Hawley, G. Nash, J. Swann and L. White (eds), Early Medieval Enquiries, 299-317, Bristol: The Proceedings of the Clifton Antiquarian Club, 9

Neuman de Vegvar, C. 2007. Remembering Jerusalem: architecture and meaning in Insular canon table arcades, in R. Moss (ed.), Making and Meaning in Insular Art, 242-57, Dublin: Four Courts Press

Ní Ghrádaigh, J. and Mullins, J. 2013. Apostolically inscribed: St Cuthbert's coffin as sacred vessel, in J. Ashbee and J. Luxford (eds), Medieval Art and Architecture in Newcastle and Northumberland, 73-89, British Archaeological Association Transactions Series, 36, Leeds: Maney

Nylén, E. and Lamm, J. P. 1988. Stones, Ships and Symbols, Stockholm: Gidlunds 
O'Sullivan, D. 2011. Normanising the North: The evidence of Anglo-Saxon and AngloScadninavian Sculpture, Medieval Archaeology, 55, 163-91

Pluskowski, A. 2006. Wolves and the Wilderness in the Middle Ages, Woodbridge: Boydell

Potter, T. W. and Andrews, R. D. 2004. Excavation and survey at St Patrick's Chapel and St Peter's Church, Heysham, Lancashire, 1977-8, Antiquaries Journal, 74, 55-134

Preston-Jones, A. and Okasha, E. 2013. Corpus of Anglo-Saxon Stone Sculpture Volume XI: Early Cornish Sculpture, Oxford: Oxford University Press

Price, N. 2002. The Viking Way: Religion and War in Late Iron Age Scandinavia, Uppsala: Uppsala Universitet

Price, N. 2010. Passing into poetry: Viking-Age mortuary drama and the origins of Norse Mythology, Medieval Archaeology, 54, 123-56

Rawlin-Cushing, H. 2011. Commemoration at York: the significance of Minster 42, 'Costaun's' grave-cover, in M. F. Reed (ed.), New Voices on Early Medieval Sculpture in Britain and Ireland, 48-56, Oxford: British Archaeological Report, British Series, 542

Schmidt, H. 1973. The Trelleborg house reconsidered, Medieval Archaeology, 17, 52-77

Schmidt, H. 2007. Reconstruction of the Lejre hall, in J. D. Niles (ed.), Beowulf and Lejre, 1038, Arizona: Arizona Center for Medieval and Renaissance Studies, Tempe, Arizona

Semple, S. 1998. A fear of the past: the place of the prehistoric burial mound in the ideology of middle and later Anglo-Saxon England, World Archaeology, 30(1), 109-26

Semple, S. 2004. Illustrations of damnation in late Anglo-Saxon manuscripts, Anglo-Saxon England, 32, 231-45

Sidebottom, P. 1999. Stone crosses of the Peak District and the 'sons of Eadwulf', Derbyshire Archaeological Journal, 119, 206-19

Sidebottom, P. 2000. Viking Age stone monuments and social identity in Derbyshire, in D.M Hadley and J. D. Richards (eds), i, 213-35, Turnhout: Brepols

Stocker, D. 2000. Monuments and merchants: irregularities in the distribution of stone sculpture in Lincolnshire and Yorkshire in the tenth century, in D. M. Hadley and J. D. Richards (eds), Cultures in Contact: Scandinavian Settlement in England in the Ninth and Tenth Centuries, 179-212, Turnhout: Brepols

Stocker, D. and Everson, P. 2001. Five towns funerals: decoding diversity in Danelaw stone sculpture, in J. Graham-Campbell, R. Hall, J. Jesch and D. N. Parsons (eds), Vikings and the Danelaw, 223-44, Oxford: Oxbow 
Thompson, V. 2004. Dying and Death in Later Anglo-Saxon England, Woodbridge: Boydell

Tweddle, D., Biddle, M. and Kjølbye-Biddle, B. 1995. Corpus of Anglo-Saxon Stone Sculpture Volume IV: South-East England, Oxford: Oxford University Press

Williams, H. 2006. Death and Memory in Early Medieval Britain, Cambridge: Cambridge University Press

Williams, H. 2011. Remembering elites: early medieval stone crosses as commemorative technologies, in L. Boye, P. Ethelberg, L. Heidemann Lutz, S. Kleingärtner, P. Kruse, L. Matthes and A. B. Sørensen (eds), Arkaologi i Slesvig/Archaologie in Schleswig. Sonderband 'Det 61. nternationale Sachsensymposion 2010' Haderslev, Denmark, 13-32, Neumünster: Wachholtz

Williams, H. 2015. Beowulf and archaeology: megaliths imagined and encountered in Early Medieval Europe, in M. Diaz-Guardamino Uribe, L. García Sanjuán and D. Wheatley (eds), The Lives of Prehistoric Monuments in Iron Age, Roman and Medieval Europe, 77-97, Oxford: Oxford University Press

Youngs, S. (ed.) 1989. 'The Works of Angels': Masterpieces of Celtic Metalwork, 6th-gth Centuries $A D$, London: British Museum 